\title{
Marriages of Convenience: Explaining Party Mergers in Europe
}

\author{
Raimondas Ibenskas, University of Southampton
}

While party mergers can have important implications for the development of party systems, their causes have not been studied in a large- $n$ comparative study. Using a new data set that covers 24 European democracies in the postwar period, this study shows that parties merge to overcome electoral thresholds or to form one of the two or three largest parties with an important role in the formation of government coalitions. However, mergers are not motivated by the goal to establish a majority, strongly dominant or largest party. The costs of mergers include ideological differences and various transaction costs related to reaching and implementing merger agreements. These transaction costs are lower if parties previously cooperated and if the partisanship of their voters is low.

W hy do political parties merge? The literature does not yet provide a systematic comparative study on this question, even if party mergers, defined in this research as the amalgamation of two or more independent parties into a single party organization, have important implications for democracy. Mergers (fusion) can contribute to the consolidation and higher quality of new democratic regimes by facilitating the formation of stable parties, avoiding the "wastage of votes" and reducing excessive party system fragmentation (Cox 1997; Lipset and Rokkan 1967). In the short term, however, by changing party supply, mergers reduce, or even destroy, the information value of party labels for voters and could impede voter representation and accountability. Either way, understanding the outcomes of the process of party system formation and stabilization in older democracies, as well as the instability of party systems in a large number of third wave democracies, is impossible without considering the role of party fusion. Furthermore, mergers can significantly change party systems in those countries with institutionalized party systems. For example, the fusion leading to the formation of the Christian Democratic Appeal in the Netherlands substantially reduced party system fragmentation and contributed to the elimination of the CatholicProtestant divide in the Dutch party system. When com- bined with other forms of party instability, multiple mergers may even lead to the wholesale change in the party system, as the case of Italy since the early 1990s demonstrates.

Mergers also affect government coalition politics. When the party system is fragmented, mergers of incumbent parties contribute to the effectiveness and stability of governments (Hopkin 1999; Kohno 1997). Conversely, the absence of fusion impedes effective governance, as the examples of the center-right governments in Poland in 1997-2001 and in Romania in 1996-2000 demonstrate (Shafir 2001; Szczerbiak 2004). At a more theoretical level, mergers (and splits) are important for the theoretical and empirical research on coalition politics because they disprove the common assumption in those studies of exogenous party identities and size (Laver and Kato 2001).

Yet another reason to study mergers is their empirical relevance. Fusion is not extremely rare: the data set collected for this study records 94 mergers in 24 European democracies. On average, fusion occurs in every third electoral period. Moreover, mergers are substantially more frequent in some countries (e.g., the Baltic states).

Nevertheless, in contrast to the very extensive literature on the mergers of business companies (Haleblian et al. 2009), the study of fusions of political parties is mostly limited

Raimondas Ibenskas (raimondas.ibenskas@gmail.com) is a lecturer at the University of Southampton, Southampton, United Kingdom.

The research leading to this publication has been undertaken mainly during the author's doctoral research at Trinity College Dublin, Ireland, funded by the Irish Reserch Council Post-Graduate Scholarship, and postdoctoral fellowship at the Centre for European Studies (CERGU) and Department of Political Science at the University of Gothenburg, Sweden, funded by the Swedish Institute (Visby Programme, grant number 00445/2012). The research has also received funding from the Marie Sklodowska-Curie Actions Programme (Intra-European Individual Fellowship grant number 330446 PARTYINSTABILITY). This financial support is gratefully acknowledged. Data and supporting materials necessary to reproduce the numerical results in the article are available in the JOP Dataverse (https://dataverse.harvard.edu/dataverse/jop). An online appendix with supplementary material is available at http://dx.doi.org/10.1086/683685.

The Journal of Politics, volume 78, number 2. Published online January 8, 2016. http://dx.doi.org/10.1086/683685

(C) 2016 by the Southern Political Science Association. All rights reserved. 0022-3816/2016/7802-0002\$10.00 
to a number of case, or small- $n$, comparative studies. This study advances the knowledge on party mergers both theoretically and empirically. In theoretical terms, the research develops an explanatory framework that identifies the costs and benefits of mergers by building on the previous studies of this phenomenon and the theories of government and electoral coalitions and legislative party switching. This framework integrates some relatively well-established explanations with more innovative arguments on how potential gains in office benefits affect mergers. Specifically, building on the typology of legislative party systems by Laver and Benoit (2015), we argue that fusion may be motivated by the goals to establish a party that has a legislative majority, is "strongly dominant," or is one of the two or three key parties in the party system. Additionally, parties may merge to achieve legislative plurality. Empirically, the study provides the very first large- $n$ analysis of mergers using an original data set that we created specifically for this research by the careful examination of the party systems in 24 established and new European democracies in the postwar period. The results of statistical analyses support the existing arguments in the literature and one of the officeseeking hypotheses.

The next three sections of the article present the theoretical framework, data and measurement issues, and the results of statistical analysis. The final section concludes.

\section{THEORETICAL EXPECTATIONS}

The causes of party mergers are relatively understudied both theoretically and empirically. The literature consists mostly of case studies examining mergers in Canada (Bélanger and Godbout 2010), France (Haegel 2004; Knapp 2003), Germany (Olsen 2007; Poguntke 1998), Italy (Bordandini, Di Virgilio, and Raniolo 2008; Rizzi 1974), Japan (Kohno 1997), Malawi (Rakner, Svasand, and Khembo 2007), the Netherlands (Lees, Hough, and Keith 2010), South Korea (Kim 1997; Park 2010), and other countries. Ware (2009) and Coffé and Torenvlied (2008) provide more theoretical accounts of mergers. The two most common factors explaining mergers in those studies are ideological or policy similarities and electoral gains due to the increased ability of component parties to overcome electoral thresholds. Other, less stressed factors include the access to financial resources, rebranding opportunities, previous cooperation, electoral decline, the loss of governmental office, and the change of the party leadership and/or the dominant coalition. Another approach is to examine mergers in the context of broader phenomena, such as electoral coordination (Cox 1997), party formation, change, and persistence (Bolleyer 2013; Hug 2001; Rose and Mackie 1988; Spirova 2007), or electoral volatility (Birch 2003; Casal-Bertoa, Deegan-Krause, and Haughton 2015; Sikk 2005).
Given the lack of a clear theory of mergers in the literature, we draw on the theories explaining political phenomena that are conceptually related to fusion. Specifically, we identify the costs and benefits (in terms of votes, office, and policy) incurred by parties when forming electoral and government coalitions and by individual legislators who switch parties. We then examine (also building on the existing literature on party fusion) how much the costs and benefits of these phenomena are applicable to mergers. Electoral and government coalitions, unlike mergers, are temporary and do not involve the integration of party organizations. Legislative party switching, in contrast, can be conceptualized as a permanent coalition akin to a merger, but the members of this coalition are an individual member of parliament (MP) and his or her new party rather than multiple parties. Taking these differences into consideration allows us to identify the costs and benefits of mergers. More specifically, in the remainder of this section we first discuss electoral and office benefits. Next, we focus on the costs related to ideological compromises as well as various transaction costs.

\section{Electoral benefits}

A number of studies show that parties form electoral coalitions to increase their legislative seat share (Blais and Indridason 2007; Ferrara and Herron 2005; Golder 2005; Kaminski 2001). Coalitions are vote or seat superadditive (subadditive) if they provide their members with a higher (lower) share of the vote or seats than the total share that these parties would obtain when running separately (Kaminski 2001). Superadditivity may arise because of the ideological closeness between parties or more likely owing to the mechanical and strategic effects of electoral institutions (i.e., the coalition is more likely to overcome electoral thresholds and attract strategic voters than its member parties; Kaminski 2001, 296). According to the latter logic, parties form electoral coalitions if they expect a bonus in terms of legislative seats due to disproportional electoral institutions (Duverger 1954). Such gains in legislative seats are likely when the combined vote share of the parties in the coalition is close to the electoral threshold (Blais and Indridason 2007).

Mergers, in a similar way to electoral coalitions, can be motivated by smaller parties' desire to obtain a higher seat share by overcoming electoral thresholds (Bélanger and Godbout 2010; Coffé and Torenvlied 2008; Knapp 2003; Olsen 2007; Rakner, Svasand, and Khembo 2007). These studies suggest that a higher permanency of a merger, as compared to a electoral coalition, may be both an advantage and disadvantage in gaining additional legislative seats. On the one hand, being temporary, electoral coalitions are more flexi- 
ble in responding to changing circumstances in the electoral market (Ware 2009, 91). On the other hand, in comparison to an electoral coalition, a merged party may run more efficient election campaigns, achieve higher clarity of its policy positions, or be more credible in re-positioning itself to a more attractive location on the main dimension of party competition (Bélanger and Godbout 2010; Ware 2009). While future studies should examine the contextual conditions that affect the relative advantages of electoral coalitions and mergers in terms of helping parties to overcome electoral thresholds, the most relevant implication of these arguments for this study is that both forms of party cooperation are suitable for achieving this goal. This suggests the following hypothesis:

Electoral Thresholds Hypothesis. A merger is more likely if the expected size of the merged party is close to the electoral threshold.

\section{Office benefits}

An important strand in the literature on legislative party switching emphasizes the incentives for individual switching created by parties' competition for governmental office. Specifically, to capture how potential gains in office payoffs lead to legislative party switching, Laver and Kato (2001) and Laver and Benoit (2003) have applied such concepts from the coalition literature as power indices (Banzhaf 1965; Shapley and Shubik 1954) and dominant parties (Peleg 1981). A similar logic may also explain mergers, especially because they involve the change of party affiliation of multiple legislators, and thus they have a greater potential than individual party switching to improve the bargaining position of the component parties in the process of coalition formation.

To develop one explanatory account about how the goal of achieving a stronger bargaining position drives mergers, this research builds on the exhaustive classification of legislative party systems provided by Laver and Benoit (2015). This typology captures the impact of "constitutionally binding arithmetical constraints on legislative bargaining” (276) that arise due to the need for coalitions to win the majority support in the legislature. Specifically, Laver and Benoit (2015) distinguish between five types of party systems depending on whether the largest party can form a winning coalition on its own and, if not, whether two-party winning coalitions among the three largest parties are possible. ${ }^{1}$ Thus, their classification includes: type A system with a single winning party; type B system with a "strongly dominant" largest party that can form a two-party coalition with either the second-

1. Here and below, the simple majority of seats is assumed to be a winning threshold. or the third-largest largest party while the latter two can not form a winning coalition; type C or "top-three" system, in which any pair of the three largest parties can form a winning coalition; type D or "top-two" system, in which the only two-party winning coalition is that between the two largest parties; and type E or "open" system, in which no two-party winning coalition is possible. They show that the type of legislative party system has a strong effect on the empirical patterns of the duration of government formation, the type of governments that form, and government termination.

Laver and Benoit's typology implies that parties' bargaining positions, and, consequently, their expected office benefits, depend on the type of the legislative party system and parties' size rankings. This is because these two variables affect whether the party can undermine a winning coalition that excludes it by tempting at least one party in this coalition to defect and form a two-party winning coalition with itself (Laver and Benoit 2015, 280). Specifically, this typology of party systems points to three situations when the party is in a privileged bargaining position: (1) when it has a full legislative majority in the system with a single winning party, (2) when it is the largest and strongly dominant party, and (3) when it is one of the three largest parties in a top-three system or one of the two largest parties in a top-two system. We therefore expect that the probability of a merger increases when the merged party is likely to be in one of these privileged positions. In what follows, we discuss each of these situations in turn, and derive testable hypotheses.

Party merger to obtain legislative majority. The first case is most straightforward, as the majority party is by definition included in all winning coalitions. Thus, we expect that mergers that provide the component parties with full majority are more likely.

Majority Party Hypothesis. A merger is more likely if the expected size of the merged party is close to the majority legislative threshold.

Party merger to establish a strongly dominant party. Strong dominance also provides the party with a privileged bargaining position because it can form two-party winning coalitions with either the second- or the third-largest party, and possibly some of the smaller parties, while all other winning coalitions have to include the second- and thirdlargest parties. This means that, if the largest party is excluded from a winning coalition, it can undermine this coalition by tempting either of these two parties (and possibly some other parties) to form a two-party winning coalition with itself (Laver and Benoit 2015, 280). In contrast, if either of the second- or third-largest parties, and possibly some of 
the smaller parties, are excluded from a winning coalition, each of them can tempt only the largest party to defect and form a two-party winning coalition.

To derive a testable implication of this theoretical logic, we seek to uncover the size of the party at which it is most likely to become strongly dominant. ${ }^{2}$ To this end, table 1 presents the constraints on the size of the three largest parties in the system with a strongly dominant party (and other types of legislative party systems). The table indicates that the largest party can become strongly dominant only if its seat share is higher than half the winning threshold but lower than the winning threshold (see the second cell from the top in the third column of the table).

To identify the value of this size threshold more precisely, we draw on the computational analysis of Laver and Benoit (2003), which provides all possible configurations of legislative seat distributions $(6,292,018$ in total) in the 100 -seat legislature when the number of legislative parties varies between 3 and 10. For each set of legislatures with a different number of parties, and for each value of party size, we compute the share of parties that belong to all possible combinations of the type of the legislative party system and party size rank (for example, the largest party in a top-two system, the second-largest party in a top-three system, the thirdlargest party in an open system, etc.). ${ }^{3}$ The solid line in figure 1 shows, for the values of party size between $1 \%$ and $50 \%$, the share of these combinations (the mean value across eight sets of legislatures with a different number of parties is used) in which the party is strongly dominant. In line with the results reported in table 1 , the share of combinations with a strongly dominant party is above 0 only when party size is between $25 \%$ and $50 \%$. However, this share is higher than 0.5 only when party size is between $38 \%$ and $50 \%$. The latter result is intuitive because, when the largest party is closer to the majority of seats, there is a broader range of the values of the size of other parties compatible with the requirement that each of these parties can form a winning coalition with the largest party.

2. An alternative empirical test would establish whether the merger would lead to a situation in which (1) the merged party would become the largest party, (2) it would be able to form winning coalitions with the second- and third-largest parties, and (3) the latter would not be able to obtain the majority of seats together. However, this approach is problematic because of the high uncertainty about the postmerger party system. Specifically, even small changes in the legislative seat shares of any of the parties due to, for example, party switching by individual legislators or changes in parties' electoral support, could lead to changes in the type of the party system (Laver and Benoit 2015).

3. The results of this analysis are provided in appendix B.
While the results presented in table 1 and figure 1 do not specify the exact size threshold under which the party becomes strongly dominant, they suggest that it is most likely when the expected size of the merged party is close to $40 \%$. Thus, we expect that, if the merger is driven by the goal to establish a strongly dominant party, it should be more likely when the expected size of the merged party is close to $40 \%$.

Strong Dominance Hypothesis. A merger is more likely if the expected size of the merged party is close to the threshold of $40 \%$.

Party merger to found one of the two or three largest parties. The three largest parties in a top-three system or the two largest parties in a top-two system, while in a weaker position than the majority or strongly dominant party, also have important advantages in coalition formation. In a topthree system any pair of the three largest parties can form a winning coalition, and all majority coalitions include at least two of them. Thus, if any of these parties is excluded from a majority coalition, it can tempt either of the remaining two parties in this coalition to defect by forming a winning coalition with itself. A top-two system privileges the two largest parties, since the only two-party winning coalition possible is that between them, and all majority coalitions have to include at least one of these parties. Thus, if one of the two largest parties is excluded from a winning coalition, it can persuade the other party in this coalition to defect by establishing a majority coalition with itself.

The party is most likely to become one of the three largest parties in a top-three system or one of the two largest parties in a top-two system when its size is somewhat above half the winning threshold. Specifically, according to table 1, the largest and second-largest parties must have at least one quarter of seats in a top-three system. Moreover, the size of the third-largest party equal to or above one quarter of seats is a sufficient condition for a top-three system. The size of the largest party above one quarter of seats is also a necessary condition for a top-two system. Furthermore, if the largest and third-largest parties can not form a winning coalition, and the merged party becomes the second-largest party, the seat share of at least one quarter of seats is a sufficient condition for the merged party to achieve a top-two system.

Additionally, figure 1 shows that the share of the combinations of party system type and party size rank at which the party is either one of the three largest parties in a topthree system or one of the two largest parties in a top-two system is higher than 0.5 when party size is between $29 \%$ and $36 \%$. Thus, the seat share of around $30 \%$ of the total 
Table 1. The Size of the Three Largest Parties under Different Types of the Legislative Party System

\begin{tabular}{|c|c|c|c|c|}
\hline \multirow[b]{2}{*}{ Legislative Party System } & \multirow[b]{2}{*}{ Party System Constraints } & \multicolumn{3}{|c|}{ Conditions for the Size of Individual Parties } \\
\hline & & $P_{1}$ & $P_{2}$ & $P_{3}$ \\
\hline A: Single winning party & $S_{1} \geq W$ & $\begin{array}{c}S_{1} \geq W \\
\text { (sufficient) }\end{array}$ & & $\begin{array}{c}S_{3}<W / 2 \\
\text { (necessary) }\end{array}$ \\
\hline B: Strongly dominant party & $\begin{array}{l}S_{1}+S_{2} \geq W \\
S_{1}+S_{3} \geq W \\
S_{2}+S_{3}<W\end{array}$ & $\begin{array}{c}W \overline{/ 2<S_{1}<} W \\
\text { (necessary) }\end{array}$ & & $\begin{array}{c}S_{3}<W / 2 \\
\text { (necessary) }\end{array}$ \\
\hline C: Top-three & $\begin{array}{l}S_{1}+S_{2} \geq W \\
S_{1}+S_{3} \geq W \\
S_{2}+S_{3} \geq W\end{array}$ & $\begin{array}{c}W / 2 \leq S_{1}<W \\
\text { (necessary) }\end{array}$ & $\begin{array}{c}S_{2} \geq W / 2 \\
\text { (necessary) }\end{array}$ & $\begin{array}{c}S_{3} \geq W / 2 \\
\text { (sufficient) }\end{array}$ \\
\hline D: Top-two & $\begin{array}{l}S_{1}+S_{2} \geq W \\
S_{1}+S_{3}<W \\
S_{2}+S_{3}<W\end{array}$ & $\begin{array}{c}W / 2<S_{1}<W \\
\text { (necessary) }\end{array}$ & $\begin{array}{c}S_{2} \geq W / 2 \\
\text { (sufficient if } \\
S_{1}+S_{3}<W \text { ) }\end{array}$ & $\begin{array}{c}S_{3}<W / 2 \\
\text { (necessary) }\end{array}$ \\
\hline E: Open & $\begin{array}{l}S_{1}+S_{2}<W \\
S_{1}+S_{3}<W \\
S_{2}+S_{3}<W\end{array}$ & $\begin{array}{l}S_{1}<W / 2 \\
\text { (sufficient) }\end{array}$ & $\begin{array}{c}S_{2}<W / 2 \\
\text { (necessary) }\end{array}$ & $\begin{array}{c}S_{3}<W / 2 \\
\text { (necessary) }\end{array}$ \\
\hline
\end{tabular}

Note. Based on Laver and Benoit (2015). $P_{1}, P_{2}$, and $P_{3}$, and $S_{1}, S_{2}$, and $S_{3}$ denote the three largest parties and their seat shares, respectively. An additional constraint for the systems of types $\mathrm{B}, \mathrm{C}, \mathrm{D}$, and $\mathrm{E}$ is $S_{1}<W$. The cells in bold font indicate a majority or strongly dominant party; the cells in italics show the one of the top three parties in type C system or one of the top two parties in type D system. Proofs are provided in appendix A.

provides the party with a good chance to hold this advantageous position.

Half the Winning Threshold Hypothesis. A merger is more likely if the expected size of the merged party is close to $30 \%$.

\section{Conditions under which a merger is unlikely to provide} office benefits. Other combinations of party system type and party size rank than those described above are less likely to provide parties with a privileged bargaining position. Specifically, in a system with a majority party, all parties but the majority party are irrelevant for the formation of winning coalitions. In a system with a strongly dominant party, the ability of the latter to potentially play all other parties off against each other disadvantages these parties even if some of them (i.e., the second- or third-largest parties and, possibly, some smaller parties) are able to establish two-party winning coalitions with the strongly dominant party. In a top-three system, all but the three largest parties are so-called dummy parties that are not pivotal in the formation of majority coalitions. Moreover, all but the two largest parties in a top-two system are disadvantaged because the two largest parties dominate the process of coalition formation. Finally, open systems do not privilege any of the parties because none of them can participate in a two-party winning coalition.

Importantly, these combinations of party system type and party size rank are more likely to occur when the size of the party is below half the winning threshold. Figure 1 shows that the share of the combinations of party size rank and party system type in which the party is in one of these less advantaged positions is more than 0.5 when party size is below $28 \%$. Moreover, table 1 demonstrates that the size of all but the two largest parties must be below half the winning threshold in the systems with majority and strongly dominant parties. In a top-three system, the seat share of all but the three largest parties is by definition lower than one quarter of the total. Similarly, in a top-two system all but the two largest parties must have the seat share that is lower than half the winning threshold. The size equal to or below half the winning threshold is also either the sufficient (for the largest party) or necessary (for the second-largest party) condition for open systems.

Party merger to form the largest legislative party. Further insights on when mergers could potentially provide office benefits can be derived from the sequential bargaining models of government coalition formation, which frequently assume that the largest party gets the right to form a government and predict that it would be included in government as its leading party (Glasgow, Golder, and Golder 2011). Thus, a merger that establishes the largest legislative party could lead to substantial office gains (Kohno 1997; Spirova 2007). A similar argument has been made in the case of electoral coalitions: Golder $(2006,174)$ argues that even seat subadditive electoral coalitions may be formed if they 


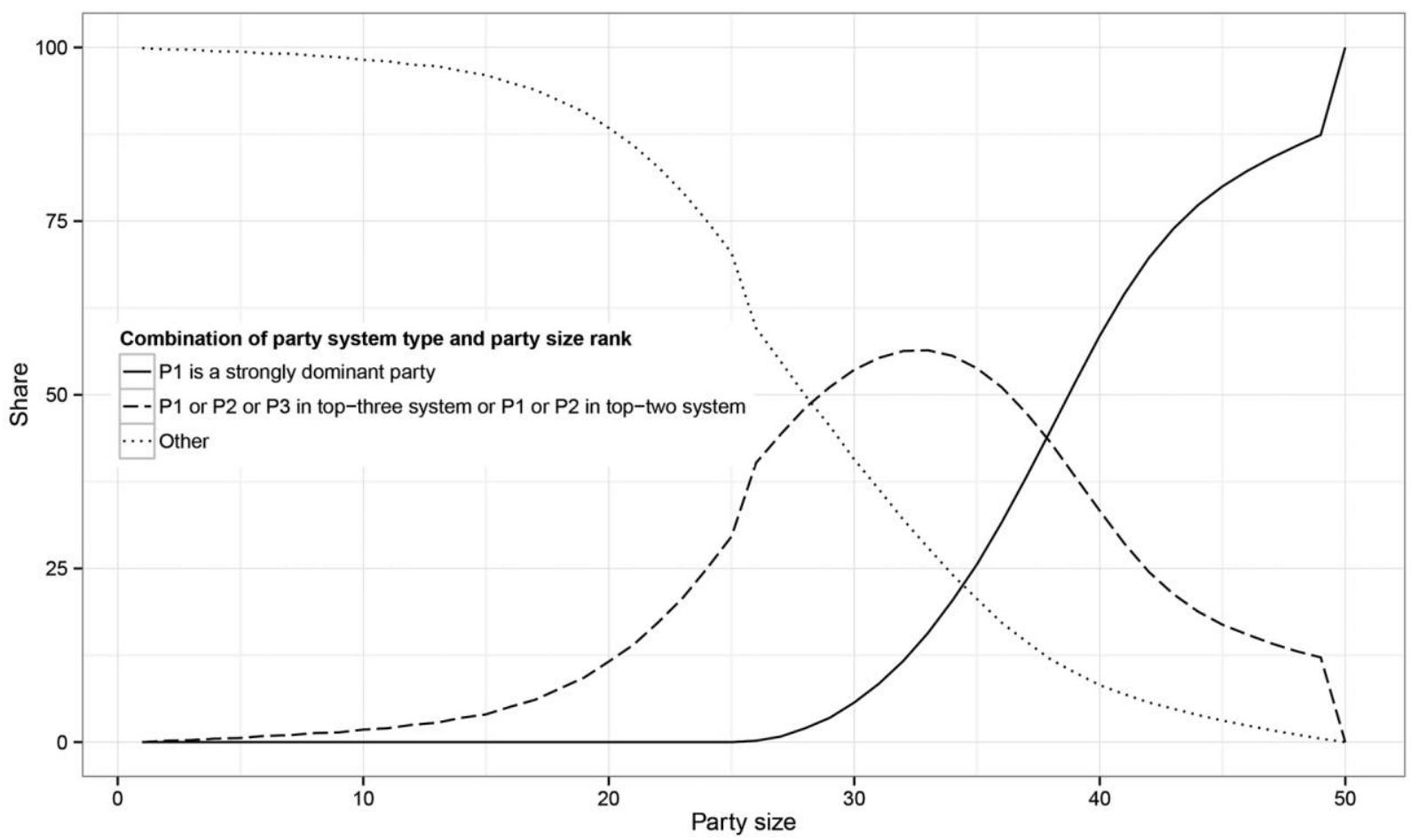

Figure 1. Combinations of party system type and party size rank: shares for party size. Note that shares for each combination of party system type and party size rank are provided in appendix $B$.

increase parties' chances to become the largest bloc in the legislature, thus obtaining the right to form a government (see also Ibenskas Forthcoming). This suggests that

Largest Party Hypothesis. A merger is more likely if the expected size of the merged party is close to the size of the largest legislative party.

The role of institutions. Institutions such as the investiture vote, bicameralism or semi-presidentialism also affect the formation of government coalitions and, by extension, officeseeking incentives for mergers. The detailed examination of the effect of those institutions on mergers is beyond the scope of this research, but additional analyses presented in appendix D (appendix available online) suggest very limited evidence to the notion that these institutions affect mergers.

\section{Ideological differences and transaction costs}

While mergers may provide parties with substantial electoral and office benefits, they can also impose significant costs. Ideological compromises are one type of such costs. According to the coalition theory, ideologically distant parties are less likely to form government and electoral coalitions (De Swaan 1973; Budge and Laver 1992; Golder 2006). Switcher MPs are also more likely to switch to those parties whose policy preferences are closely aligned to their own (Desposato 2006; Heller and Mershon 2008; McElroy and Benoit 2009). Many studies on mergers also identify ideological similarities between parties as the key precondition for mergers (e.g., Coffé and Torenvlied 2008).

Ideology Hypothesis. Mergers are more likely between ideologically close parties.

The literature on government and electoral coalitions suggests two types of transaction costs that are also equally or, possibly, even more relevant in the case of mergers. First, party elites need to spend a lot of time and effort when bargaining on a joint policy program, conflict resolution mechanisms, the division of office positions in the merged party (including its leadership) and, possibly, the sharing of election candidacies and executive office positions. Furthermore, parties need to integrate their organizations at both central and local levels. Overall, time and effort spent on achieving merger agreements and implementing them imply significant opportunity costs in terms of office, policy and votes, as also suggested to some extent by previous studies on mergers (Haegel 2004; Ware 2009).

Second, parties face difficulties in achieving credible commitments when forming government coalitions due to the combination of the uncertainty about the preferences of 
potential coalition partners and the risk of their opportunistic behavior (Lupia and Strøm 2008). In a similar vein, mergers involve a substantial risk of opportunism by partner parties; consequently, trust between them is crucial for completing the merger process (Lees et al. 2010; Ware 2009). Especially the smaller component party faces a risk that its larger partner would renege on a merger agreement by revoking its previous policy concessions or increasing its share of office positions or election candidacies above that agreed at the time of the merger. The component party that is a victim of such a defection by its partner is nevertheless unlikely to withdraw from the merged party owing to the costs related to the reestablishment of an independent party organization. ${ }^{4}$

Previous experience of governing together creates inertia that reduces bargaining costs and decreases the uncertainty about partners' behavior in the coalition government by increasing their familiarity with each other (Bäck and Dumont 2007; Franklin and Mackie 1983; Martin and Stevenson 2010; Warwick 1996). It follows that previous cooperation in government and electoral coalitions could also reduce the bargaining costs of a merger and increase the credibility of a merger agreement. Many issues that parties bargain over when founding a merged party are similar to those that they need to resolve when forming government and electoral coalitions. Thus, previous compromises on policy or agreements on the division of electoral candidacies and/or government portfolios and procedures for conflict resolution can provide a viable focal point in the merger negotiations. Moreover, previous cooperation experience allows party leaders and members to find out about each other's preferences and establish trust (Coffé and Torenvlied 2008). Indeed, as Mair $(1990,131)$ argues, parties merge when "external friendships ... prove overriding."

Previous Cooperation Hypothesis. Previous cooperation increases the probability of a merger.

Moreover, the party switching literature suggests that partisan voters value the loyalty of legislators (Mershon and Shvetsova 2013) and are unlikely to follow the switcher MP to his or her new party (Desposato 2006; Kreuzer and Pettai 2009). Similarly, in the case of mergers, the costs

4. For example, previous supporters of this component party may have transferred their loyalties to the merged party. Voters may also consider the members of the splinter party as noncredible because of frequent changes in their party affiliation (Mershon and Shvetsova 2013). Legal requirements for the registration of a new party further increase the costs of the formation of a splinter party (Hug 2001). owing to the discontent of partisan voters with the merged party may be substantial (Knapp 2003; Mair 1997). The permanent alliance of a party with previous competitors may lead to the exit of many activists and the defection of partisan voters. Voter partisanship tends to increase with the age of the party (Converse 1969; Dalton and Weldon 2007; Huber, Kernell, and Leoni 2005; Lupu and Stokes 2009), which suggests that the costs of a merger are lower for younger parties. $^{5}$

Party Age Hypothesis. Mergers are more likely between younger parties.

The literatures on partisan dealignment (Dalton and Wattenberg 2000) and party organizational models (Katz and Mair 1995) suggest alternative hypotheses on the effect of party age. According to the first literature, the decline in voter attachments to established parties in most Western democracies in the last few decades should have increased the propensity of these parties to merge with other parties. The second literature implies that the emergence of the catch-all and especially cartel parties with weaker linkages to the society should have also increased the propensity of established parties to collude through mergers (Krouwel 2012).

\section{DATA AND MEASUREMENT}

To test our theoretical expectations, we assembled a new data set recording mergers in 24 countries in the European Union with a population of at least 1 million. This data set considers almost all democratic electoral periods (280 in total, listed in appendix C) in these countries in the postwar period. The data set provides information about the identity of component and merged parties, their electoral performance, and a number of other predictor variables used in the statistical analysis presented in the next section.

Collecting data on mergers that involve minor parties, most of which are also of little substantive importance, is challenging owing to the lack of reliable data sources about these parties. For instance, 111 parties or electoral coalitions participated in the 1991 election in Poland. Tracking organizational developments of this number of parties is close to an impossible task. Thus, the data set records mergers only

5. Younger parties also tend to be less institutionalized internally (Harmel and Janda 1994), both in terms of the routinization of internal rules and procedures and the attachment of the members to the party (value infusion). Greater institutionalization on both of these dimensions should reduce the propensity of parties to change through a merger. 
if at least two of the component parties were supported by at least $1 \%$ of voters in the last legislative election before the merger. ${ }^{6}$ The data set also does not consider as component parties those splinter groups that were established previously in the same electoral period and thus had no electoral record before they merged.

In total, the data set includes 94 mergers formed by 216 parties. These mergers occurred in 59 electoral periods, more than one fifth of the total number of periods in the sample; $79 \%$ or $84 \%$ of these merger parties were formed by two parties. The data set includes two very large mergers - the Union of Democratic Forces in Bulgaria formed by 11 parties in 1997 and the merger of 8 parties leading to the establishment of the Union of Democratic Centre in Spain in 1978. ${ }^{7}$ Figure 2 presents the distribution of the merged parties across countries. The figure shows a relatively large variation at the country level. On average, postCommunist democracies have more mergers than established democracies of Europe, which substantiates previous more impressionistic accounts in the literature (Gallagher, Laver, and Mair 2011; Mair 1997).

The data to be used in the statistical analysis are organized in a dyadic format and includes all possible pairs of political parties in a given electoral period, regardless of whether they merged or not. The unit of analysis is a partydyad-electoral-period and the dependent variable is dichotomous $(1-$ merger between the parties took place in the given electoral period, 0 -absence of a merger). As an example of how data are structured, consider the 1987 election in the United Kingdom, in which five parties obtained at least $1 \%$ of the vote: the Conservatives, Labour, Liberals, Social Democrats (the latter two in a electoral coalition), and the Scottish Nationalist Party. For the 1987-92 electoral period in the United Kingdom the data include 10 dyads. The dependent variable takes the value of 1 for the dyad of the Liberals and the Social Democratic Party (because these two parties merged in 1988) and 0 for the remaining 9 dyads. There are in total 210 dyads that resulted in mergers, but 83 of these were the result of the two "megamergers." Since the inclusion of these two mergers would have a substantial effect on the results of statistical analyses (Poast 2010), the sample used for the main analysis whose results are presented below excludes two electoral

6. In the cases where two or more parties participated in an electoral coalition and their individual vote shares are not available, they were estimated as the product of the coalition's vote share and the share of seats of the party from the total share of seats of the coalition.

7. In fact, each of these mergers involved more parties, but the estimated vote share of these other component parties was below $1 \%$.

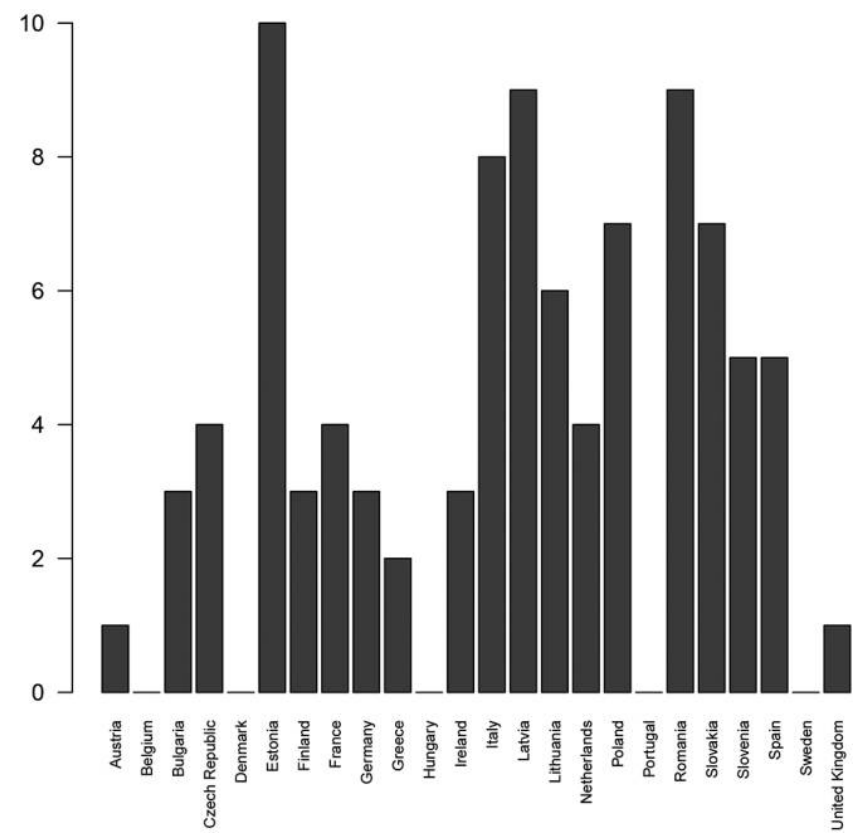

Figure 2. Number of party mergers in Europe in the postwar period

periods (Spain 1977-79 and Bulgaria 1994-97) in which these mergers occurred. The sample without these two periods includes 121 dyads that resulted in mergers. ${ }^{8}$

\section{Independent variables}

To test the hypotheses focusing on office and electoral benefits of mergers, we construct five variables that take into consideration how close the expected support of the merged party is to different thresholds implied by the hypotheses. In the models presented below the expected support of the merged party is measured as the total vote share of the parties in the dyad in the election that took place at the beginning of the electoral period under consideration. The use of vote shares, rather that seat shares, is more in line with the electoral thresholds hypothesis, since the former captures more accurately the chances of small parties without parliamentary representation to overcome electoral thresholds. The use of parties' vote shares to test the office-seeking hypotheses is also justifiable, given that mergers are motivated by potential office benefits not only in the current term (when small partners without legislative representation can not help the larger party to enter government) but also in future legislative terms (when the seats gained as a result of the representation of the voters of

8. Six more dyads besides the ones resulting from "mega-mergers" were removed because one more merger took place in Spain (in the period between 1977 and 1979). 
the smaller partner can improve the chances of the larger party to enter government). ${ }^{9}$

Lijphart's (1994) effective electoral threshold in the last election before a merger, whose values are provided by Carey and Hix (2011), captures the size of the electoral threshold. The vote share of the largest party in the election that took place at the beginning of the electoral period is used as a measure of the size of the largest party threshold. If one of the parties in the dyad is already the largest party, the support of the second-largest party captures the size of this threshold. The other thresholds, implied by half the winning threshold, strong dominance, and majority party hypotheses, are $30 \%, 40 \%$, and $50 \%$, respectively. With parties' expected support and threshold values at hand, we compute each measure as the square root of the absolute difference between these two quantities. The use of square root takes into consideration that the same absolute increase in the expected size of the merged party matters more if the size of the party is close to the threshold. ${ }^{10}$ Lower values of each measure therefore indicate that the expected support of the merged party is closer to the threshold. Thus, parties in the dyads that have lower scores on these measures have stronger incentives to merge.

Information on party families is used to estimate ideological differences between political parties. Each party in the data set has been categorized as belonging to one of 11 party families based on the coding provided by Döring and Manow (2012); for the parties not included in that database (mostly in Central and Eastern Europe), we have used various other sources, such as the handbooks on political parties, in particular, Bugajski (2002). As explained in greater detail in appendix $\mathrm{C}$, the degree of ideological closeness was measured by two dichotomous variables that capture whether parties belong to the same party family or similar families (e.g., Communist and Social Democratic or Christian Democratic and conservative parties). The use of party families (as opposed to more precise estimates of party ideology provided by the Comparative Manifesto Project or expert surveys) maximizes the number of cases covered at the cost of data quality. Appendix $\mathrm{C}$ justifies this

9. However, alternative empirical analyses that use seat shares lead to similar results as those presented in the next section.

10. The square root transformation accounts better (e.g., in comparison to the logarithmic transformation) for the theoretical argument that the thresholds that provide office or electoral benefits to parties are not very firmly established, and therefore differences between party size and these thresholds matter substantively even if party size is quite far away from the threshold. The results of statistical analyses, however, remain substantively similar when the logarithmic transformation is used. choice by showing that the number of cases covered by those alternative sources is too low for the large- $n$ analysis conducted in this study.

To test the previous cooperation hypothesis, two dichotomous variables are used. The first variable indicates whether the parties in the dyad were part of the same government in the previous electoral period. The second one captures their participation in the same electoral coalition in the election that started the electoral period under consideration. Electoral coalitions are operationalized here as joint candidate nominations or lists. In contrast to weaker forms of electoral cooperation, such as public commitments to govern together after the election, joint candidates or candidate lists involve a greater degree of cooperation, which should substantially decrease bargaining costs and increase the trust between parties. Finally, the average of the logged age of the parties in the dyad captures the strength of the partisanship of their voters. Appendix $\mathrm{C}$ provides the descriptive statistics of the variables used in the analysis.

\section{ANALYSIS AND RESULTS}

The observations in the sample are clustered by parties, elections, and countries, which raise the possibility that some unobserved variables at the level of these units have an effect on the dependent variable. To account for this issue, randomeffects logistic regression models (Gelman and Hill 2007; Greene 2008) with varying intercepts at the level of countries and electoral periods, are used. Table 2 presents six model specifications, which differ with regard to the inclusion of the variables that capture potential office gains. Specifically, since there is high correlation between the office-seeking variables, models 1-3 and 5 include one of these variables each; model 4 includes all variables derived from the typology of party systems by Laver and Benoit (2015) but not the difference between the expected size of the merged party and the size of the largest party; finally, model 6 includes all predictor variables.

Regression analyses provide substantial leverage in accounting for mergers: they support most theoretical expectations. ${ }^{11}$ Given how the variables that test the electoral thresholds hypothesis and the office-seeking hypotheses are constructed, we expect to find a negative coefficient indicating that an increase in the values of each of these var-

11. The mean predicted probability of a merger for the dyads that actually resulted in mergers is much higher (0.15) than for the dyads that did not lead to mergers (0.01) (based on the estimates of model 6). Also, the results remain robust in a number of additional analyses presented in appendix D. 
Table 2. Random-Effects Logit Models of Party Mergers

\begin{tabular}{|c|c|c|c|c|c|c|}
\hline & Model 1 & Model 2 & Model 3 & Model 4 & Model 5 & Model 6 \\
\hline Intercept & $\begin{array}{c}-3.36^{\star * *} \\
(.76)\end{array}$ & $\begin{array}{c}-5.05^{\star * *} \\
(.92)\end{array}$ & $\begin{array}{c}-5.57^{\star * *} \\
(1.10)\end{array}$ & $\begin{array}{c}-4.62^{* * *} \\
(1.28)\end{array}$ & $\begin{array}{c}-4.84^{* * *} \\
(.63)\end{array}$ & $\begin{array}{c}-4.59^{* * *} \\
(1.29)\end{array}$ \\
\hline Close to electoral threshold & $\begin{array}{c}-.34^{* * *} \\
(.10)\end{array}$ & $\begin{array}{c}-.19 \\
(.10)\end{array}$ & $\begin{array}{c}-.15 \\
(.10)\end{array}$ & $\begin{array}{r}-.25^{\star} \\
(.11)\end{array}$ & $\begin{array}{c}-.19^{\star} \\
(.08)\end{array}$ & $\begin{array}{r}-.25^{\star} \\
(.11)\end{array}$ \\
\hline Close to $30 \%$ & $\begin{array}{c}-.40^{* * *} \\
(.11)\end{array}$ & & & $\begin{array}{c}-.68^{* * *} \\
(.19)\end{array}$ & & $\begin{array}{c}-.68^{* * *} \\
(.20)\end{array}$ \\
\hline Close to $40 \%$ & & $\begin{array}{l}-.07 \\
(.12)\end{array}$ & & $\begin{array}{l}.60 \\
(.44)\end{array}$ & & $\begin{array}{l}.60 \\
(.44)\end{array}$ \\
\hline Close to $50 \%$ & & & $\begin{array}{l}.00 \\
(.13)\end{array}$ & $\begin{array}{c}-.15 \\
(.36)\end{array}$ & & $\begin{array}{l}-.15 \\
(.37)\end{array}$ \\
\hline Close to the largest party & & & & & $\begin{array}{c}-.14 \\
(.09)\end{array}$ & $\begin{array}{c}-.02 \\
(.10)\end{array}$ \\
\hline Ideological similarity & $\begin{array}{l}1.15^{\star * *} \\
(.13)\end{array}$ & $\begin{array}{l}1.16^{* * *} \\
(.13)\end{array}$ & $\begin{array}{l}1.17^{\star * *} \\
(.13)\end{array}$ & $\begin{array}{l}1.17^{\star * *} \\
(.13)\end{array}$ & $\begin{array}{l}1.17^{\star * *} \\
(.13)\end{array}$ & $\begin{array}{l}1.17^{\star \star *} \\
(.13)\end{array}$ \\
\hline Electoral coalition & $\begin{array}{l}2.64^{\star * \star} \\
(.24)\end{array}$ & $\begin{array}{l}2.56^{\star * \star} \\
(.24)\end{array}$ & $\begin{array}{l}2.55^{\star \star \star} \\
(.24)\end{array}$ & $\begin{array}{l}2.62^{\star * \star} \\
(.24)\end{array}$ & $\begin{array}{l}2.56^{\star * \star} \\
(.24)\end{array}$ & $\begin{array}{l}2.62^{\star * *} \\
(.24)\end{array}$ \\
\hline Government coalition & $\begin{array}{l}.89^{* *} \\
(.27)\end{array}$ & $\begin{array}{l}.89^{* *} \\
(.28)\end{array}$ & $\begin{array}{l}.91^{\star *} \\
(.28)\end{array}$ & $\begin{array}{l}.94^{* * *} \\
(.28)\end{array}$ & $\begin{array}{l}.91^{* \star *} \\
(.27)\end{array}$ & $\begin{array}{l}.94^{\star * *} \\
(.28)\end{array}$ \\
\hline Mean (ln [party age]) & $\begin{array}{c}-.35^{\star \star} \\
(.13)\end{array}$ & $\begin{array}{c}-.31 * \\
(.13)\end{array}$ & $\begin{array}{c}-.30 * \\
(.13)\end{array}$ & $\begin{array}{c}-.33 \text { * } \\
(.13)\end{array}$ & $\begin{array}{c}-.33 \text { * } \\
(.13)\end{array}$ & $\begin{array}{c}-.33 \text { * } \\
(.13)\end{array}$ \\
\hline Log likelihood & -478.08 & -484.02 & -484.20 & -475.53 & -483.02 & -475.51 \\
\hline$N$ & 10,661 & 10,661 & 10,661 & 10,661 & 10,661 & 10,661 \\
\hline No. of electoral periods & 278 & 278 & 278 & 278 & 278 & 278 \\
\hline No. of countries & 24 & 24 & 24 & 24 & 24 & 24 \\
\hline Election-level variance & .56 & .58 & .58 & .55 & .58 & .55 \\
\hline Country-level variance & .64 & .59 & .59 & .64 & .57 & .64 \\
\hline
\end{tabular}

Note. Entries in the table are coefficients of the maximum likelihood logit models with random intercept terms at the level of countries and electoral periods. Standard errors in parentheses. Given how the variables that test five "threshold hypotheses" are constructed, we expect to find negative coefficients indicating that an increase in those variables leads to a decrease in the probability of a party merger.

${ }^{*} p<.05$.

${ }^{* *} p<.01$.

${ }^{* * *} p<.001$ (two-tailed).

iables decreases the probability of a merger. Table 2 shows that this is indeed the case for the electoral threshold hypothesis. When the logged difference between the expected support of the merged party and the effective electoral threshold is changed from one standard deviation below the mean (1.5) to the mean (3.3), the probability of a merger is $45 \%$ lower (the $95 \%$ confidence interval is $23 \%$ and $61 \%$ ). ${ }^{12}$

Turning to the hypotheses that capture potential office benefits of a merger, the results support only the half the winning threshold hypothesis. Specifically, a change in the square-rooted difference between the expected support of the merged party and the threshold of $30 \%$ from one standard deviation below the mean (2.7) to the mean (3.9)

12. The estimates of model 1 are used for computing this and other quantities presented in this section. decreases the probability of a merger by $39 \%$ (the $95 \%$ confidence interval is $54 \%$ and $20 \%$ ). In contrast, the coefficients of the variables that capture parties' incentives to establish the largest party, a strongly dominant party, or a majority party, are not statistically significant in any of the models. This is an interesting finding that requires a more detailed explanation than permitted by the available space here. However, it should be noted that this result is in line with one of the key explanations of minority governments, according to which they form when the electoral costs of the participation in government are high (Laver and Schofield 1990; Mitchell and Nyblade 2008; Strøm 1990). In a similar vein, the formation of plurality or majority parties through mergers may have higher electoral costs in comparison to the establishment of merged parties with the seat share below one third of the total. Specifically, in the countries with multiple social 
cleavages and/or proportional electoral systems, as those examined here, mergers that lead to the establishment of very large parties are likely to leave a large share of the electorate unrepresented, leading to the emergence of viable new parties.

The comparison between the merger of the Socialist Party (PSI) and the Democratic Socialist Party (PSDI) in Italy in 1966 and the absence of a merger between the Centre Party (C) and the Liberal People's Party (FP) in Sweden in the late 2000s and early 2010s illustrates the logic behind the half the winning threshold hypothesis. While the two pairs of parties were similar with regard to most factors of mergers, the extent to which mergers could help them to obtain a stronger bargaining position was different. ${ }^{13}$ The combined support of the social-democratic parties in Italy in the 1963 election was approximately 20\%. Their merger aimed to create the "third force" in Italian politics, a party that would have undermined the strong dominance of the largest party - the Christian Democracy — by being able to form a majority coalition either with it or with the second-largest party, the Italian Communist Party (the latter obtained 26\% of seats in 1963; Rizzi 1974). Had this plan succeeded, the party system would have shifted from the system with the strongly dominant Christian Democracy to a top-three system in which any two-party coalitions among the Christian Democrats, Socialists, and Communists would have had a legislative majority. In contrast, Swedish liberal parties did not merge even if the merged party would have likely become the third largest party. The combined size of the two liberal parties (14\%-15\% of the vote) would have been insufficient to switch the type of the party system from a top-two system, in which the Social Democrats (30\%-35\% of the vote) and the Moderates (25\%-30\% of the vote) were the major parties, to a top-three system.

Ideological similarity also emerges as a very important predictor of mergers. While this variable has three categories, it is treated as continuous in the analyses presented below, since the effect of the parties in the dyad belonging to "similar" families is approximately twice lower than that of the parties belonging to the same family (both effects are relative to the category "different families"). More precisely,

13. All four parties were electorally viable and therefore mergers would have increased their vote-seat ratio only marginally. Also, ideological differences between the parties were limited and they had the experience of government cooperation. Specifically, in the early 1960s the PSI shifted toward the centre-left positions already occupied by the PSDI, and the two parties participated in government together since 1963 (Rizzi 1974). Similarly, in the 2000s the Centre Party adopted a liberal program, which was similar to that of the FP. The two parties were members of centre-right governments in the period between 2006 and 2014. as parties' ideological similarity increases by one category, the probability of a merger is, all else being equal, $219 \%$ higher (the $95 \%$ confidence interval is between $150 \%$ and 304\%).

The effect of previous electoral cooperation is still stronger. A premerger electoral coalition increases the probability of a merger by 13.9 times ( 8.9 and 21.7), all else being equal. The effect of the experience of being in government in the previous legislative term is weaker, but still substantial: it increases the probability of a merger by 2.4 times (1.4 and 4.2 ). The case of the Union for a Popular Movement (UMP) in France illustrates the importance of previous party cooperation: it was established by diverse smaller center-right parties only after a long period of electoral and government cooperation between those parties (Haegel 2004).

Younger parties are also more likely to merge in line with the party age hypothesis (and in contradiction to the alternative expectations about the effect of party age on mergers). The increase in the average logged age of parties in the dyad, from the mean value (2.5) to one standard deviation above the mean (3.7), decreases the probability of a merger by $34 \%$ (52\% and $10 \%)$. The comparison between liberal parties in Lithuania (the Liberal Union [LLS] and the Centre Union [CS] and the Netherlands (the People's Party for Freedom and Democracy [VVD] and D66), whose average logged age in the early and mid-2000s was close to the mean value of the sample (the parties in Lithuania) and one standard deviation above the mean (the Dutch parties), demonstrates the importance of voter and member attachments as a crucial factor of mergers. Following their nationallevel electoral cooperation in the 2000 parliamentary election, the two liberal parties in Lithuania merged in 2003, both to assure their survival as legislative parties and to establish the leading center-right party. Being founded in the early 1990s, neither of the two parties had strong partisan following in the electorate, which resulted in their wildly fluctuating electoral fortunes in the period between 1992 and 2000. Thus, the risk of partisan backlash by voters was limited. In contrast, while the Dutch liberal parties considered a merger in the mid2000s, the widespread dislike of the VVD and the merger idea itself by the voters and members of D66 and, to a smaller extent, different organizational cultures of the two parties, were key reasons for why the merger did not take place despite the cooperation of the parties in government in the 1990s and mid-2000s and similar party programmes (Lucardie and Voerman 2006, 133-41).

\section{CONCLUSION}

The goal of this research was to understand why parties choose to form permanent coalitions with other parties 
through the foundation of a unified party organization. The research proposes an explanatory framework that emphasizes various costs and benefits of mergers and tests this framework using a new data set on mergers in 24 established and new democracies in Europe. The framework incorporates a variety of the costs of mergers, such as ideological differences between parties and various transaction costs related to reaching and implementing merger agreements. These transaction costs are lower if parties previously cooperated and if the partisanship of their voters is low. Furthermore, the framework suggests that the expected benefits of mergers include not only the improved ability of the component parties to overcome electoral thresholds, as suggested by multiple previous studies, but also better chances to obtain executive office. Specifically, parties could use mergers to achieve legislative majority or strong dominance, to establish the largest party, or to constitute one of the two or three key parties in the formation of government coalitions.

The empirical analyses demonstrate the importance of ideological differences, transaction costs and electoral benefits for the formation of merged parties. They also show that mergers are motivated by parties' goal to establish one of the two or three key players in the party system with enough seats to participate in two-party winning coalitions. However, no support was found to the hypotheses that mergers are motivated by parties' goal to establish majority, strongly dominant, or largest parties, which provides an important theoretical puzzle for future research.

These findings have important implications for the literature on government and electoral coalitions. With regard to the former, the study uncovers how party competition for the executive office shapes party identities and size through mergers. With regard to the latter, this article shows that incentives for mergers created by potential electoral and office gains are quite similar to those provided by electoral coalitions. At the same time, many electoral coalitions serve as the first, intermediary step toward the full integration of party organizations. Building on these insights, future research should further investigate how parties choose between different forms of cooperation.

Furthermore, the findings of this study suggest that the costs and benefits of mergers may be quite different from those considered in the literature on legislative party switching. Some of these differences arise because a merger changes the party affiliation of multiple legislators at once. Thus, for example, while the benefits and costs of party switching by individual legislators depends on how advantaged the largest two parties are in coalition formation (Laver and Benoit 2003), a merger may be motivated by a bigger goal of achieving such advantages. Explanations of individual party switching and mergers differ also because a merger involves the integration of component parties' organizations. Consequently, the transaction costs related to achieving and implementing a merger agreement are higher than in the case of individual party switching. Thus, the literature on party switching would benefit from the theoretical and empirical distinction between the switching of individual legislators and the switching related to various forms of party instability, including party mergers.

\section{ACKNOWLEDGMENTS}

I would like to thank Ken Benoit, Nicole Bolleyer, Adriana Bunea, Thomas Daeubler, Kevin Deegan-Krause, Michael Gallagher, Sona Golder, Tim Hicks, Simon Hug, Seth Jolly, Gail McElroy, Michael Marsh, Daniel Naurin, Jonathan Polk, Marina Povitkina, Jan Rovny, Linn Sandberg, Allan Sikk, Maria Spirova, Robert Thomson, Federico Vegetti, Jack Veugelers, Steven Wolinetz, three anonymous reviewers and the editors of the Journal of Politics for their valuable comments.

\section{REFERENCES}

Bäck, Hanna, and Patrick Dumont. 2007. "Combining Large- $n$ and Small$n$ Strategies: The Way Forward in Coalition Research.” West European Politics 30 (3): 467-501.

Banzhaf, John F. 1965. "Weighted Voting Doesn't Work: A Mathematical Analysis.” Rutgers Law Review 19 (4): 317-43.

Bélanger, Éric, and Jean-Francois Godbout. 2010. "Why Do Parties Merge? The Case of the Conservative Party of Canada." Parliamentary Affairs 63 (1): 41-65.

Birch, Sarah. 2003. Electoral Systems and Political Transformation in PostCommunist Europe. New York: Palgrave.

Blais, André, and Indridi H. Indridason. 2007. "Making Candidates Count: The Logic of Electoral Alliances in Two-Round Legislative Elections." Lournal of Politics 69 (1): 193-205.

Bolleyer, Nicole. 2013. New Parties in Old Party Systems: Persistence and Decline in Seventeen Democracies. Oxford: Oxford University Press.

Bordandini, Paola, Aldo Di Virgilio, and Francesco Raniolo. 2008. "The Birth of a Party: The Case of the Italian Partito Democratico." South European Society and Politics 13 (3): 303-24.

Budge, Ian, and Michael Laver. 1992. "Coalition Theory, Government Policy and Party Policy." In Ian Budge and Michael Laver, eds., Party Policy and Government Coalitions. New York: St. Martin's Press, 1-14.

Bugajski, Janusz. 2002. Political Parties of Eastern Europe: A Guide to Politics in the Post-Communist Era. New York: ME Sharpe.

Carey, John M., and Simon Hix. 2011. "The Electoral Sweet Spot: LowMagnitude Proportional Electoral Systems." American Journal of POlitical Science 55 (2): 383-97.

Casal-Bertoa, Fernando, Kevin Deegan-Krause, and Tim Haughton. 2015. "Splitting the Difference: Measuring Institutional and Electoral Volatility." Paper presented at the workshop "Party System Stability and Electoral Volatility: Its Measurement and Implications," University of Nottingham, February 26-27, 2015.

Coffé, Hilde, and René Torenvlied. 2008. "Explanatory Factors for the Merger of Political Parties." Working Paper, Center for the Study of Democracy, University of California, Irvine.

Converse, Philip. 1969. "Of Time and Partisan Stability." Comparative Political Studies 2 (1): 139-71.

Cox, Gary W. 1997. Making Votes Count: Strategic Coordination in Worlds Electoral Systems. Cambridge: Cambridge University Press. 
Dalton, Russel J., and Martin P. Wattenberg. 2000. "The Decline of Party Identification." In Russel J. Dalton and Martin P. Wattenberg, eds., Parties without Partisans: Political Change in Advanced Industrial Democracies. Oxford: Oxford University Press, 9-36.

Dalton, Russell J., and Steven Weldon. 2007. "Partisanship and Party System Institutionalization." Partv Politics 13 (2): 179-96.

De Swaan, Abram. 1973. Coalition Theories and Government Formation. Amsterdam: Elsevier.

Desposato, Scott W. 2006. "Parties for Rent? Ambition, Ideology, and Party Switching in Brazil's Chamber of Deputies." American Journal of Political Science 50 (1): 62-80.

Döring, Holger, and Philip Manow. 2012. "Parliament and Government Composition Database (ParlGov).” http://www.parlgov.org (accessed May 14, 2015).

Duverger, Maurice. 1954. Political Parties: Their Organization and Activity in the Modern State. London: Methuen.

Ferrara, Federico, and Erik S. Herron. 2005. "Going It Alone? Strategic Entry under Mixed Electoral Rules." American Journal of Political Science 49 (1): 16-31.

Franklin, Mark N., and Thomas T. Mackie. 1983. "Familiarity and Inertia in the Formation of Governing Coalitions in Parliamentary Democracies." British Journal of Political Science 13 (3): 275-98.

Gallagher, Michael, Michael Laver, and Peter Mair. 2011. Representative Government in Modern Europe. London: McGraw Hill.

Gelman, Andrew, and Jennifer Hill. 2007. Data Analysis Using Regression and Multi-Level/Hierarchical Models. Cambridge: Cambridge University Press

Glasgow, Garrett, Matt Golder, and Sona N. Golder. 2011. "Who 'Wins'? Determining the Party of the Prime Minister." American Journal of Political Science 55 (4): 937-54.

Golder, Sona N. 2005. "Pre-Electoral Coalitions in Comparative Perspective: A Test of Existing Hypotheses." Electoral Studies 24 (4): 643-63.

Golder, Sona N. 2006. The Logic of Pre-Electoral Coalition Formation. Columbus: Ohio State University Press.

Greene, William H. 2008. Econometric Analysis. 6th ed. Upper Saddle River, NJ: Prentice Hall.

Haegel, Florence. 2004. "The Transformation of the French Right: Institutional Imperatives and Organizational Changes." French Politics 2 (2): 185-202.

Haleblian, Jerayr, Cynthia E. Devers, Gerry McNamara, Mason A. Carpenter, and Robert B. Davison. 2009. "Taking Stock of What We Know about Mergers and Acquisitions: A Review and Research Agenda." Lournal of Management 40 (5): 469-502.

Harmel, Robert, and Kenneth Janda. 1994. "An Integrated Theory of Party Goals and Party Change." Lournal of Theoretical Politics 6 (3): 259-87.

Heller, William B., and Carol Mershon. 2008. "Dealing in Discipline: Party Switching and Legislative Voting in the Italian Chamber of Deputies, 1988-2000." American Journal of Political Science 52 (4): 910-25.

Hopkin, Jonathan. 1999. Party Formation and Democratic Transition in Spain: The Creation and Collapse of the Union of the Democratic Centre. Basingstoke: Palgrave Macmillan.

Huber, John D., Georgia Kernell, and Eduardo L. Leoni. 2005. "Institutional Context, Cognitive Resources and Party Attachments across Democracies." Political Analvsis 13 (4): 365-86.

Hug, Simon. 2001. Altering Party Systems: Strategic Behavior and the Emergence of New Political Parties in Western Democracies. Ann Arbor: University of Michigan Press.

Ibenskas, Raimondas. Forthcoming. "Understanding Pre-Electoral Coalitions in Central and Eastern Europe." British Journal of Political Science.

Kaminski, Marek M. 2001. "Coalitional Stability of Multi-Party Systems: Evidence from Poland." American Journal of Political Science 45 (2): 294-312.
Katz, Richard S., and Peter Mair. 1995. "Changing Models of Party Organization and Party Democracy.” Party Politics 1 (1): 5-28.

Kim, Hee Min. 1997. "Rational Choice Theory and Third World Politics: The 1990 Party Merger in Korea." Comparative Politics 30 (1): 83-100.

Knapp, Andrew. 2003. "From the Gaullist Movement to the President's Party." In Jocelyne Evans, ed., The French Party System. Manchester: Manchester University Press, 121-36.

Kohno, Masaru. 1997. Japan's Postwar Party Politics. Princeton, NJ: Princeton University Press.

Kreuzer, Marcus, and Vello Pettai. 2009. "Party Switching, Party Systems, and Political Representation." In William B. Heller and Carol Mershon, eds., Political Parties and Legislative Party Switching. New York: Palgrave, 265-85.

Krouwel, André. 2012. Party Transformations in Europe. Albany: SUNY Press.

Laver, Michael, and Kenneth Benoit. 2003. "The Evolution of Party Systems between Elections." American Journal of Political Science 47 (2): 215-33.

Laver, Michael, and Kenneth Benoit. 2015. "The Basic Arithmetic of Legislative Decisions." American Journal of Political Science 59 (2): 275-91.

Laver, Michael, and Junko Kato. 2001. "Dynamic Approaches to Government Formation and the Generic Instability of Decisive Structures in Japan." Electoral Studies 20 (4): 509-27.

Laver, Michael, and Norman Schofield. 1990. Multiparty Government. Oxford: Oxford University Press.

Lees, Charles, Dan Hough, and Dan Keith. 2010. "Towards an Analytical Framework for Party Mergers: Operationalising the Cases of the German Left Party and the Dutch Green Left." West European Politics 33 (6): 1299-317.

Lijphart, Arendt. 1994. Electoral Systems and Party Systems: A Study of TwentySeven Democracies, 1945-1990. Oxford: Oxford University Press.

Lipset, Seymour M., and Stein Rokkan. 1967. Party Systems and Voter Alignments: Cross-National Perspectives. New York: Free Press.

Lucardie, Paul, and Gerrit Voerman. 2006. "Eccentric Yet Powerful: The Position of the Liberals in the Dutch Party System." In Patrick van Schie and Paul Lucardie, eds., The Dividing Line between Success and Failure: A Comparison of Liberalism in the Netherlands and Germany in the 19th and 20th Centuries. Berlin: Lit Verlag, 121-42.

Lupia, Arthur, and Kaare Strøm. 2008. "Coalition Theory and Cabinet Governance: An Introduction.” In Wolfgang C Müller, Torbjörn Bergman, and Kaare Strøm, eds., Cabinets and Coalition Bargaining: The Democratic Life Cycle in Western Europe. Oxford: Oxford University Press, 51-83.

Lupu, Noam, and Susan Stokes. 2009. "The Social Bases of Political Parties in Argentina." Latin American Research Review 44 (1): 58-87.

Mair, Peter. 1990. "The Electoral Payoffs of Fission and Fusion." British Journal of Political Science 20 (1): 131-42.

Mair, Peter. 1997. Party System Change: Approaches and Interpretations. Oxford: Oxford University Press.

Martin, Lanny W., and Randolph T. Stevenson. 2010. "The Conditional Impact of Incumbency on Government Formation." American Political Science Review 104 (3): 503-18.

McElroy, Gail, and Kenneth Benoit. 2009. "Party Group Switching in the European Parliament." In William B. Heller and Carol Mershon, eds., Political Parties and Legislative Party Switching. New York: Palgrave, 147-72.

Mershon, Carol, and Olga Shvetsova. 2013. Party System Change in Legislatures Worldwide: Moving Outside the Electoral Arena. Cambridge: Cambridge University Press.

Mitchell, Paul, and Benjamin Nyblade. 2008. "Government Formation and Cabinet Type in Parliamentary Democracies." In Kaare Strøm, Wolfgang C. Müller, and Torbjörn Bergman, eds., Cabinets and Coalition Bargaining: The Democractic Life Cycle in Western Europe. Oxford: Oxford University Press, 201-35. 
Olsen, Jonathan. 2007. "The Merger of the PDS and WASG: From Eastern German Regional Party to National Radical Left Party?” German Politics 16 (2): 205-21.

Park, Kyungmee. 2010. "Party Mergers and Splits in New Democracies: The Case of South Korea (1987-2007)." Government and Opposition 45 (4): 531-52.

Peleg, Bazalel. 1981. "Coalition Formation in Simple Games with Dominant Players." International Journal of Game Theory 1 (1): 11-13.

Poast, Paul. 2010. "Mis(Using) Dyadic Data to Analyze Multilateral Events." Political Analysis 18 (4): 403-25.

Poguntke, Thomas. 1998. "Alliance 90/The Greens in East Germany: From Vanguard to Insignificance?" Party Politics 4 (1): 33.

Rakner, Lise, Lars Svasand, and Nixon S. Khembo. 2007. "Fissions and Fusions, Foes and Friends: Party System Restructuring in Malawi in the 2004 General Elections.” Comparative Political Studies 40 (9): 1112-37.

Rizzi, Felice. 1974. "From Socialist Unification to Socialist Scission 196669: Socialist Unification and the Italian Party System." Government and Opposition 9 (2): 146-64.

Rose, Robert, and Thomas T. Mackie. 1988. "Do Parties Persist or Fail? The Big Trade-off Facing Organizations.” In Kay Lawson and Peter H. Merkl, eds., When Parties Fail: Emerging Alternative Organizations. Princeton, NJ: Princeton University Press, 109-34.
Shafir, Michael. 2001. “The Ciorbea Government and Democratization: A Preliminary Assessment.” In David Phninnemore and Duncan Light, eds., Post-Communist Romania: Coming to Terms with Transition. Basingstoke: Palgrave Houndmills, 79-103.

Shapley, Lloyd S., and Martin Shubik. 1954. "A Method for Evaluating the Distribution of Power in a Committee System." American Political Science Review 48 (3): 787-92.

Sikk, Allan. 2005. "How Unstable? Volatility and the Genuinely New parties in Eastern Europe." European Journal of Political Research 44 (3): 391412.

Spirova, Maria. 2007. Political Parties in Post-Communist Societies: Formation, Persistence, and Change. New York: Palgrave Macmillan.

Strøm, Kaare. 1990. Minority Government and Majority Rule. Cambridge: Cambridge University Press.

Szczerbiak, Aleks. 2004. “The Polish Centre-Right's (Last?) Best Hope: The Rise and Fall of Solidarity Electoral Action." Lournal of Communist Studies and Transition Politics 20 (3): 55-79.

Ware, Alan. 2009. The Dynamics of Two-Party Politics: Party Structures and the Management of Competition. Oxford: Oxford University Press.

Warwick, Paul V. 1996. "Coalition Government Membership in West European Parliamentary Democracies." British Journal of Political Science 26 (4): 471-99. 